\title{
PENYAKIT AKAR GANODERMA PADA SENGON DI SLEMAN, YOGYAKARTA
} Ganoderma root disease on sengon in Sleman, Yogyakarta

\author{
Tri Maryono \\ Kontributor Utama, Universitas Lampung, \\ Jl. Prof. Dr. Soemantri Brodjonegoro No 1, Gedong Meneng, Bandar Lampung, Indonesia \\ email penulis korespondensi: tri.maryono@fp.unila.ac.id
}

Tanggal diterima: 07 Februari 2020, Tanggal direvisi: 09 April 2020, Disetujui terbit: 29 Juni 2020

\begin{abstract}
Ganoderma root disease in the community forest of sengon is one of the limiting factor to increase the productivity of sengon wood. This disease has been reported in West Java, East Java, South Sumatra and South Kalimantan. The survey was conducted to determine the existence of Ganoderma root disease in three sengon fields in Sleman, Yogyakarta. The existence of Ganoderma root disease was recognized based on the symptoms of diseased plants and the present of Ganoderma basidiocarp on the diseased sengon stem. The survey results on three sengon fields was succeed in finding diseased plants and also the basidiocarp of Ganoderma on the basal of the diseased plant stem. Symptoms that have been found was either dead or dying trees (few leaves left). The basidiocarp of Ganoderma on the diseased plants varies in characteristic while its young and mature. The basidiospores is ellipsoid, truncate, rough (coarsely echinulated), and double-walled. The Ganoderma colony was white and turned to yellow orange from the center. Based on this study the Ganoderma root disease in sengon plants has developed in Sleman, Yogyakarta. The presence of dead or dying trees with few leaves left between healthy sengon trees and the presence of Ganoderma basidiocarp in diseased trees are indicator of the presence of root disease in the sengon field caused by Ganoderma.
\end{abstract}

Keywords: falcataria, pathogen, root rot, sengon disease

\begin{abstract}
ABSTRAK
Penyakit akar Ganoderma pada tanaman kehutanan jenis sengon merupakan ancaman serius peningkatan produktivitas kayu sengon. Penyakit ini telah dilaporkan di Jawa Barat, Jawa Timur, Sumatera Selatan, dan Kalimantan Selatan. Kegiatan survey ini dilakukan untuk mengetahui keberadan penyakit akar Ganoderma pada tiga lahan sengon di Sleman Yogyakarta. Keberadaan penyakit akar Ganoderma didasarkan pada adanya gejala tanaman sakit dan badan buah Ganoderma pada batang sengon sakit. Hasil survey pada tiga lahan sengon berhasil menemukan tanaman sakit dan juga badan buah Ganoderma pada sekitar pangkal batang tanaman sakit. Gejala yang berhasil ditemukan berupa tanaman mati dan tanaman merana (daunnya sedikit). Badan buah Ganoderma pada tanaman sakit bervariasi karakternya ketika muda dan tua. Basidiospora dari badan buah berbentuk ellipsoid dan truncate, permukaannya kasar, dan memiliki dua lapis dinding sel. Koloni Ganoderma hasil isolasi dari badan buah berwarna putih pada awalnya dan menjadi kuning keemasan dari tengah. Berdasarkan hasil survey ini diketahui bahwa bahwa penyakit akar Ganoderma pada tanaman sengon telah berkembang di Sleman, Yogyakarta. Adanya tanaman sengon mati atau tampak merana dengan daun sedikit di antara tanaman sengon sehat dan adanya badan buah Ganoderma pada tanaman sakit adalah indikasi adanya penyakit akar pada lahan sengon yang di sebabkan oleh jamur Ganoderma.
\end{abstract}

\section{Kata kunci: falcataria, patogen, busuk akar, penyakit sengon}

\section{PENDAHULUAN}

Tanaman sengon (Falcataria moluccana (Miq.) Barneby \& J.W. Grimes) merupakan salah satu tanaman kehutanan yang banyak ditanam masyarakat Indonesia. Sentra utama tanaman sengon di Indonesia adalah pulau Jawa. Menurut data statistik produksi kehutanan tahun 2019, produksi kayu bulat jenis sengon menempati urutan ke tiga setelah akasia dan ekaliptus dengan total produksi mencapai 5,47 juta meter kubik $\left(\mathrm{m}^{3}\right)$ (Badan Pusat Statistik, 2019). Batang sengon merupakan bahan baku berbagai industri seperti industri kertas, furniture, packing box, dan juga banyak digunakan pada kontruksi perumahan (Rahmawati, Khumaida, \& Siregar, 2019).

Pada budidaya tanaman kehutanan, penyakit akar yang disebabkan oleh jamur Ganoderma merupakan permasalahan utama. 
Beberapa spesies Ganoderma dilaporkan menyerang berbagai tanaman kehutanan. G. philippii pada akasia di Malaysia dan Indonesia (Glen et al., 2009), serta pada eukaliptus di Sumatera Utara (Coetzee et al., 2011), G. Steyaertanum pada akasia di Wonogiri (Hidayati, Glen, Nurrohmah, Rimbawanto, \& Mohammed, 2014; Hidayati \& Nurrohmah, 2015a), G. lucidum dan G. applanatum pada akasia dan karet di Kalimantan Barat ((Suryantini \& Wulandari, 2018), dan Ganoderma sp. pada tanaman damar dan pinus di hutan pendidikan Sukabumi (Achmad, Herliyana, \& Permatasari, 2016; Herliyana, 2012), serta Ganoderma sp. pada tanaman peneduh jenis angsana di Yogyakarta (Widyastuti \& Riastiwi, 2013).

Khusus pada tanaman sengon, serangan Ganoderma telah dilaporkan menyerang sengon di Jawa Barat dan Jawa Timur (Herliyana, Taniwiryono, \& Minarsih, 2012; Minarsih, Lingga, Darmono, \& Herliyana, 2011) dan di Palembang dan Kalimantan Selatan (Minarsih et al., 2011). Kerugian akibat serangan Ganoderma cukup signifikan karena dapat mematikan tanaman. Menurut Herliyana et al. (2012) serangan Ganoderma dapat terjadi pada semua tanaman sengon generasi kedua pada lahan dengan sejarah Ganoderma. Selain itu upaya pengendalian penyakit akar relatif sulit dilakukan jika didasarkan pada gejala karena gejala tanaman sakit terlihat ketika serangan pada bagian akar sudah parah. Kajian ini bertujuan untuk mengetahui keberadaan penyakit akar Ganoderma pada sengon di Sleman, Yogyakarta.

\section{BAHAN DAN METODE}

\section{A. Waktu dan lokasi}

Survei penyakit akar Ganoderma dilakukan dari November 2019 - Februari 2020 pada tiga lahan sengon di Sleman, Yogyakarta. Dua lahan sengon di kecamatan Depok dengan luas masing-masing $\pm 0,25$ ha, dan satu lahan di kecamatan Ngaglik, dengan luas lahan \pm 1 ha.

\section{B. Metode}

Pengamatan tanaman sakit/mati dan tanaman yang menunjukan gejala awal serangan Ganoderma (tanaman stres dan daunnya mulai gugur) dilakukan secara visual. Pengamatan tubuh buah dilakukan pada sekitar pangkal batang tanaman sakit. Beberapa tubuh buah diambil dan dibawa ke laboratorium untuk dilakukan karaktersisasi yang meliputi: bentuk, warna, dan tangkai. Karakterisasi juga dilakukan pada basidiospora dari badan buah yang meliputi bentuk dan warnanya. Gambar tanaman sakit dan badan buah diambil dengan kamera pada ponsel pintar Samsung A10®, sedangkan gambar basidiospora diambil menggunakan kamera pada mikroskop Leica ICC50 HD. Isolasi jamur Ganoderma dilakukan dari badan buah menggunakan media PDA (potato dextrose agar).

\section{HASIL DAN PEMBAHASAN}

Tanaman sengon yang diamati pada ketiga lahan merupakan tanaman sengon berumur $4-6$ tahun. Kondisi lahan sengon yang diamati bervariasi, dua lahan dipenuhi rumput dan satu lahan tanpa rumput. Keterjadian penyakit akar Ganoderma pada tiga lahan bervariasi. Pada lahan pertama (penuh rumput) keterjadian penyakit 5\%, pada lahan kedua (tanpa rumput 40\%), dan pada lahan ketiga (penuh rumput) $1 \%$.

Gejala penyakit akar Ganoderma berhasil ditemukan pada tiga lahan sengon di Kabupaten Sleman, Yogyakarta. Gejala yang ditemukan ada dua bentuk yaitu tanaman mengering (mati) dan tanaman yang daunnya sedikit (stres/merana) (Gambar 1). Tanaman mati terkadang kulit batangnya mengelupas, mudah patah, dan roboh. Akar tanaman sakit tampak mengalami busuk kering (lapuk). Pada tanaman sakit (baik tanaman mati maupun tanaman yang belum mati) pada pangkal batangnya berhasil ditemukan badan buah Ganoderma sp (Gambar 2). Badan buah banyak berkembang pada saat musim hujan. Badan buah dapat 
muncul pada batang di atas permukaan tanah juga dari akar tanaman. Pada tanaman yang sudah roboh, badan buah dapat tumbuh jauh

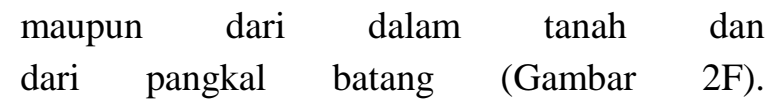
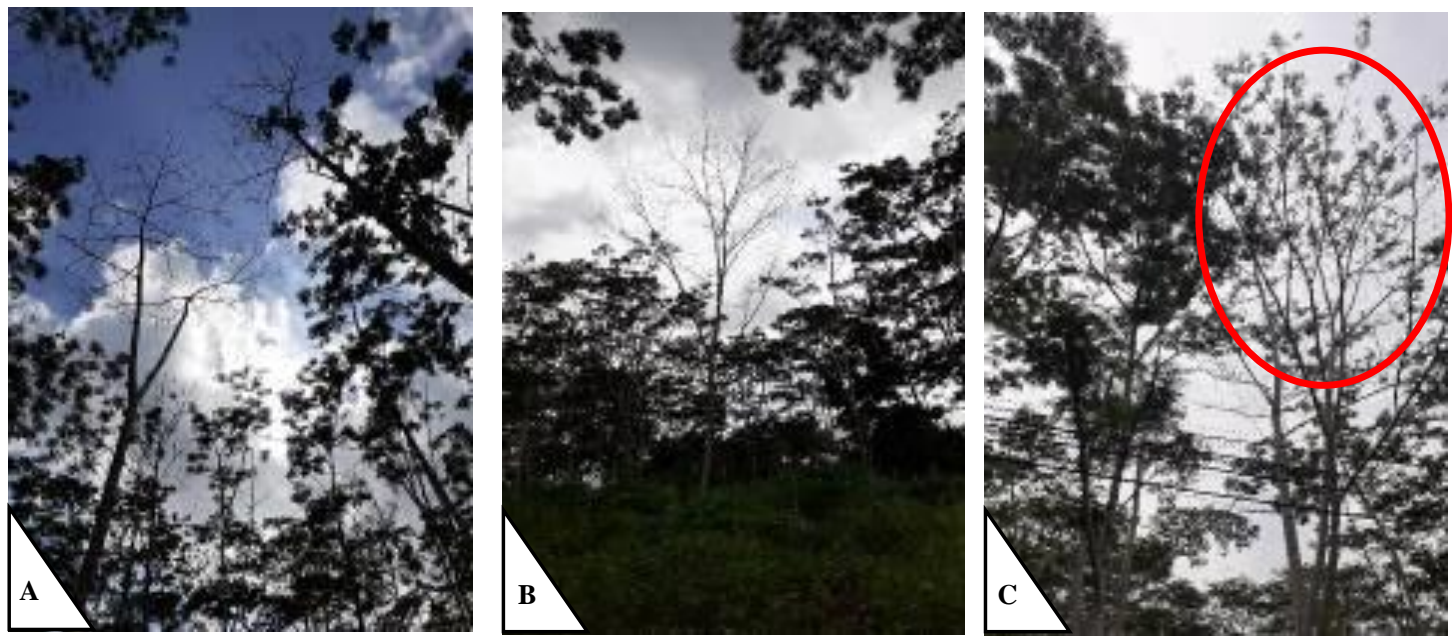

Gambar 1. Gejala penyakit akar Ganoderma pada tiga lahan sengon di Sleman, Yogyakarta. (A) Tanaman sengon mati pada lahan sengon di Kecamatan Depok, (B) Tanaman sengon mati pada lahan sengon di Kecamatan Ngaglik, dan (C) Tanaman sengon tampak merana dan daunnya gugur (lingkaran merah) pada lahan sengon di Kecamatan Depok.
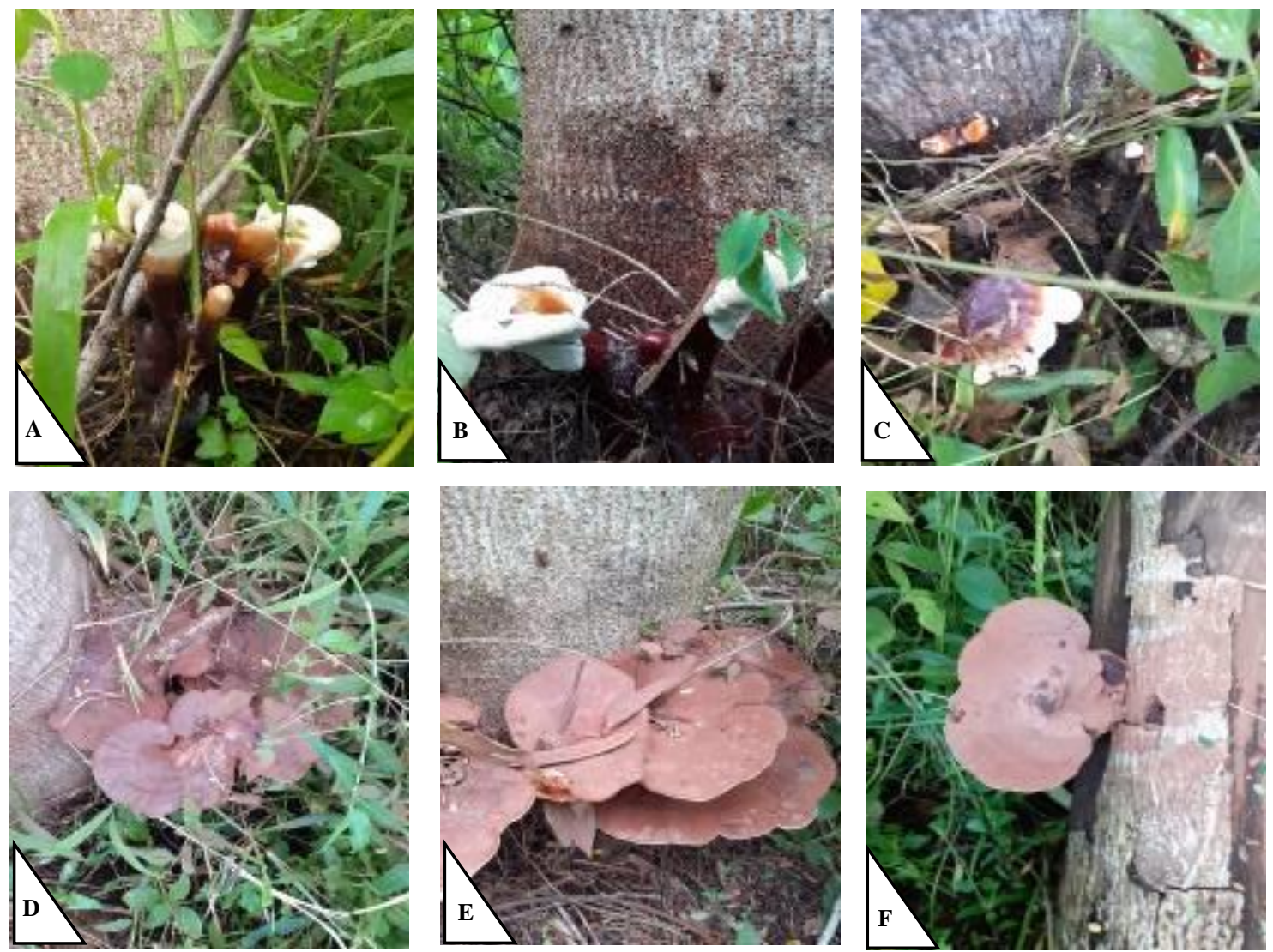

Gambar 2. Badan buah Ganoderma sp. yang ditemukan pada tanaman sengon sakit di Sleman, Yogyakarta. (A, C, D, F) Badan buah Ganoderma sp. pada lahan sengon di Kecamatan Depok, dan (B dan E) Badan buah Ganoderma sp. pada lahan sengon di Kecamatan Ngaglik. (A-C) Badan buah muda dan (D-F) badan buah tua/matang. 
Pada awalnya badan buah berbentuk tangkai dengan ujung berwarna putih dan bagian bawahnya cokelat gelap serta mengkilap. Pada tahap lebih lanjut, ujung tangkai badan buah melebar membentuk piringan seperti kipas dan mengkilap (shiny atau laccate), berwarna putih pada tepinya, coklat gelap pada pangkalnya, dan coklat jingga pada bagian antara yang berwarna putih dan cokelat gelap. Tangkai badan buah dapat bercabang maupun tidak. Permukaan atas badan buah cenderung datar, mengkilap (shiny atau laccate) dengan tepi rata (smooth) dan tidak tampak adanya zona konsentris, (Gambar 2A-C). Permukaan bawah badan buah berwarna putih. Badan buah matang menjadi berwarna cokelat pada permukaan atasnya, zona konsentris tampak jelas, dan permukaan badan buah sedikit bergelombang (Gambar 2D-F), dan tangkai tetap berwarna

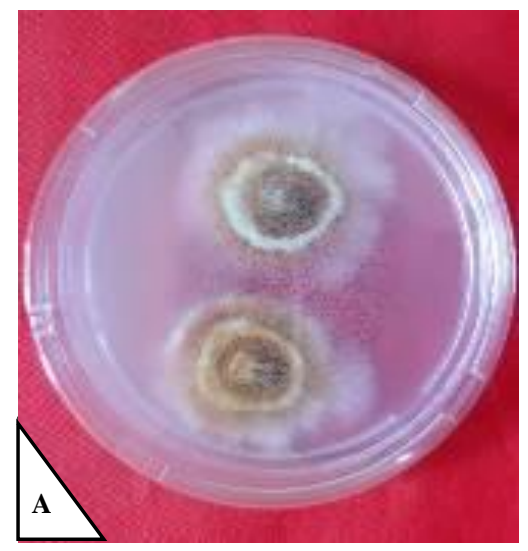

cokelat gelap serta mengkilap. Permukaan bawah badan buah berwarna putih ketika masih segar, namun berubah menjadi putih pucat (white pale) ketika kering.

Hasil isolasi didapatkan koloni jamur awalnya berwarna putih, namun berubah menjadi kuning jingga dari titik tumbuh, sedangkan ujungnya tetap putih, dan terdapat zona konsentris berwarna putih (Gambar 3). Basidiospora dari badan buah berbentuk ellipsoid dengan ujung tampak terpotong (truncate), berwarna gelap, permukaan kasar (rough atau coarsely echinulated), dan memiliki dua lapis dinding spora (Gambar 4). Ciri khas Ganoderma adalah basiodiospora truncate dan memiliki dinding dua lapis (Costa-Rezende et al., 2017; Hapuarachchi et al., 2019; Xing, Sun, Han, Cui, \& Dai, 2018).

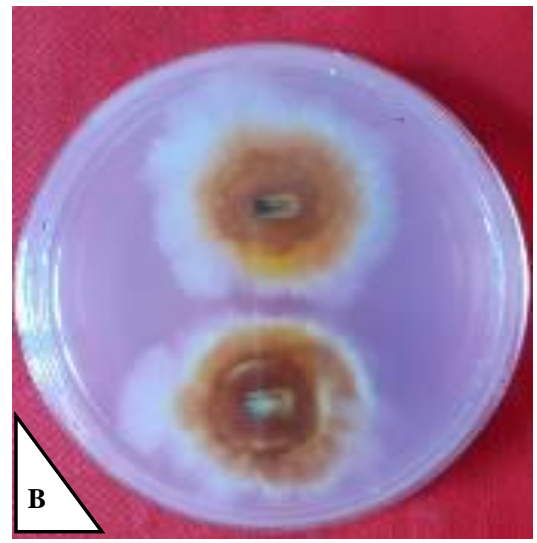

Gambar 3. Koloni jamur Ganoderma sp. hasil isolasi dari badan buah yang ditemukan pada tanaman sengon sakit di Sleman, Yogyakarta. (A) Tampak depan dan (B) tampak belakang.
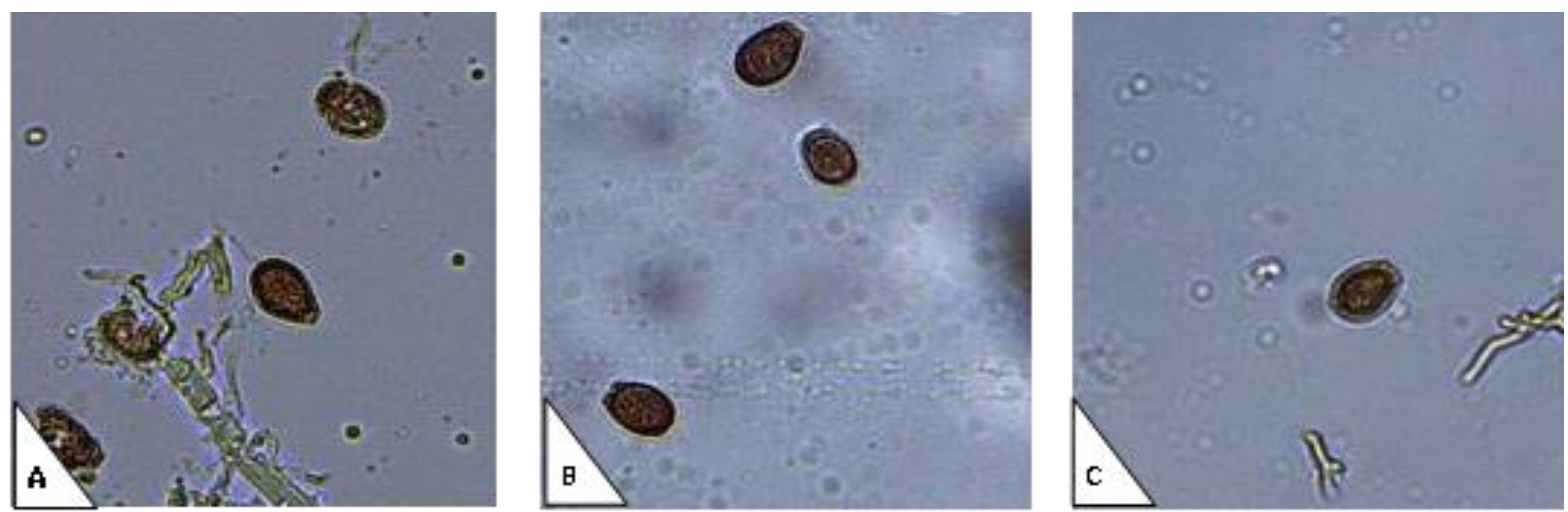

Gambar 4. Bentuk basidiospora dari badan buah Ganoderma sp. yang ditemukan pada tanaman sengon sakit di Sleman, Yogyakarta. (A) dan (C) Basidiospora Ganoderma sp. dari badan buah di lahan sengon di Kecamatan Depok, dan (B) lahan tanaman sengon di Basidiospora Ganoderma sp. dari badan buah Kecamatan Ngaglik. (perbesaran 40x). 
Berdasar tanda penyakit dan basidiospora yang didapat, jamur yang berasosiasi dengan tanaman sengon sakit (baik tanaman mati maupun tanaman yang belum mati) adalah jamur Ganoderma sp. Jamur Ganoderma telah banyak dilaporkan sebagai penyebab penyakit busuk akar pada berbagai tanaman berkayu (Coetzee et al., 2011; Glen et al., 2009; Herliyana et al., 2012; Hidayati et al., 2014; Hidayati \& Nurrohmah, 2015a; Widyastuti \& Riastiwi, 2013). Jamur Ganoderma selain sebagai patogen pada berbagai tanaman, juga dikenal sebagai obat pada pengobatan tradisional di China, Jepang, dan (Hapuarachchi, Cheng, Wen, Jeewon, \& Kakumyan, 2017; Yang \& Feng, 2013; Zhou et al., 2015).

Spesies jamur Ganoderma pada sengon di Jawa Barat dan Jawa Timur disebut sebagai G. lucidum (Herliyana et al., 2012). Berdasarkan bentuk dan warna badan buah, Ganoderma yang ditemukan pada sengon di Sleman (Yogyakarta) berbeda dengan Ganoderma pada sengon di Jawa Barat dan Jawa Timur seperti yang dilaporkan (Herliyana et al., 2012) Bentuk dan warna badan buah Ganoderma pada sengon di Sleman justru mirip dengan badan buah G. steyaertanum pada akasia di Wonogiri dan Yogyakarta seperti yang dilaporkan (Hidayati \& Hendrati, 2018; Hidayati \& Nurrohmah, 2015a, 2015b). Selain itu, bentuk dan warna koloni Ganoderma asal sengon di Sleman juga mirip dengan G. steyaertanum yang dilaporkan pada akasia di Wonogiri (Cabarroi-Hernández, VillalobosArámbula, Torres-Torres, Decock, \& GuzmánDávalos, 2019; Hidayati \& Hendrati, 2018; Hidayati \& Nurrohmah, 2015a, 2015b; Nurrohmah \& Hidayati, 2014)

Meskipun demikian, fakta-fakta tersebut belum bisa digunakan sebagai dasar untuk mengatakan bahwa jamur Ganoderma pada sengon di Sleman bukan G. lucidum tetapi G. steyaertanum. Hal ini karena kurangnya data pendukung. Untuk dapat menentukan spesies jamur Ganoderma yang ditemukan pada sengon di Sleman masih diperlukan pengkajian lebih mendetail, terutama dari aspek molekulernya. Hal ini karena jamur Ganoderma memiliki kelenturan fenotifik yang tinggi, sehingga identifikasi berdasarkan karakter morfologi sangat sulit dilakukan untuk menentukan spesies Ganoderma (Cabarroi-Hernández et al., 2019).

Di sisi lain, penanamaan jamur Ganoderma di Indonesia dengan nama G. lucidum (termasuk pada sengon) masih perlu dikaji ulang karena diduga ada kekeliruan. Penamaan G. lucidum untuk jamur Ganoderma di wilayah tropis (termasuk Indonesia) adalah misname (Wang et al., 2012). Hal ini karena secara genetik G. lucidum dari daerah tropis berbeda dengan G. lucidum asal UK (Eropa), dan pada pohon filogenetik juga membentuk lineage yang berbeda (Hennicke et al., 2016; Moncalvo, Wang, \& Hseu, 1995). Nama yang benar untuk G. lucidum dari daerah tropis adalah $\quad G$. multipelium karena G. lucidum adalah jamur Ganoderma dari daerah temperate (Wang et al., 2009). Meskipun demikian, jamur Ganoderma pada akasia di Wonogiri awalnya diidentifikasi sebagai

G. lucidum (Irianto et al., 2006) tetapi kemudian diidentifikasi ulang sebagai $G$. steyaertanum (Glen et al., 2009). Untuk itu, penelitian mengenai identitas spesies jamur Ganoderma (terutama jamur Ganoderma pada tanaman sengon) masih sangat diperlukan baik secara morfologi maupun secara molekuler.

\section{KESIMPULAN}

Hasil survei pada tiga lahan sengon ini menunjukkan bahwa penyakit akar Ganoderma pada tanaman sengon telah berkembang di Sleman, Yogyakarta. Keberadaan tanaman sengon mati atau tanaman sengon tampak merana dengan daun sedikit di antara tanaman sengon sehat, dan adanya badan buah Ganoderma pada sekitar pangkal batang sengon dapat dijadikan sebagai indikasi awal adanya penyakit akar pada lahan sengon yang di sebabkan oleh jamur Ganoderma. 


\section{UCAPAN TERIMA KASIH}

Penulis mengucapkan terima kasih kepada M. Zaidan Arka dan M. Zianur Rifky yang telah membantu dalam survey dan mengumpulkan badan buah Ganoderma.

\section{DAFTAR PUSTAKA}

Achmad, Herliyana, E. N., \& Permatasari, D. P. (2016). Luas Serangan Dan Sebaran Kejadian Penyakit Akar Merah Di Hutan Pendidikan Gunung Walat, Sukabumi. Jurnal Silvikultur Tropika, 7(1), 24-31.

Badan Pusat Statistik. (2019). Statistik Produksi Kehutanan 2019.

Cabarroi-Hernández, M., Villalobos-Arámbula, A. R., Torres-Torres, M. G., Decock, C., \& Guzmán-Dávalos, L. (2019). The Ganoderma weberianum-resinaceum lineage: Multilocus phylogenetic analysis and morphology confirm $G$. mexicanum and $G$. parvulum in the Neotropics. MycoKeys, 59, 95-131. http://doi.org/10.3897/mycokeys.59.33182

Coetzee, M. P. ., Wingfireld, B. ., Golani, G. ., Tjahjono, B., Gafur, A., \& Wingfield, M. . (2011). a Single Dominant Ganoderma Species is Responsible for Root Rot. Southern Forest : A Journal of Forest Science, 73((3-4)), 175180.

http://doi.org/http://dx.doi.org/10.2989/207026 20.2011 .639488

Costa-Rezende, D. H., Robledo, G. L., Góes-Neto, A., Reck, M. A., Crespo, E., \& DrechslerSantos, E. R. (2017). Morphological reassessment and molecular phylogenetic analyses of Amauroderma s. lat. Raised new perspectives in the generic classification of the Ganodermataceae family. Persoonia: Molecular Phylogeny and Evolution of Fungi, 39(December), 254-269. http://doi.org/10.3767/persoonia.2017.39.10

Glen, M., Bougher, N. L., Francis, A. A., Nigg, S. Q., Lee, S. S., Irianto, R., Mohammed, C. L. (2009). Ganoderma and Amauroderma species associated with root-rot disease of Acacia mangium plantation trees in Indonesia and Malaysia. Australasian Plant Pathology, 38(4), 345-356. http://doi.org/10.1071/AP09008

Hapuarachchi, K., Cheng, C., Wen, T. C., Jeewon, R., \& Kakumyan, P. (2017). Mycosphere Essays 20: Therapeutic potential of Ganoderma species: Insights into its use as traditional medicine. Mycosphere, 8(10), 1653-1694.

http://doi.org/10.5943/Mycosphere/8/10/5
Hapuarachchi, K., Karunarathna, S., McKenzie, E., Wu, X., Kakumyan, P., Hyde, K., \& TC, W. (2019). High phenotypic plasticity of Ganoderma sinense (Ganodermataceae, Polyporales) in China. Asian Journal of Mycology, 2(1), 1-47. http://doi.org/10.5943/ajom/2/1/1

Hennicke, F., Cheikh-Ali, Z., Liebisch, T., MacIáVicente, J. G., Bode, H. B., \& Piepenbring, M. (2016). Distinguishing commercially grown Ganoderma lucidum from Ganoderma lingzhi from Europe and East Asia on the basis of morphology, molecular phylogeny, and triterpenic acid profiles. Phytochemistry, 127(April), 29-37.

http://doi.org/10.1016/j.phytochem.2016.03.012

Herliyana, E. N. (2012). Laporan Awal Penyakit Busuk Akar Merah Ganoderma sp. pada Agathis sp. (Damar) di Hutan Pendidikan Gunung Walat, Sukabumi, Jawa Barat. Jurnal Silvikultur Tropika, 3(2), 102-107.

Herliyana, E. N., Taniwiryono, D., \& Minarsih, H. (2012). Penyakit akar Ganoderma sp. pada Sengon di Jawa Barat dan Jawa Timur. Jurnal Manajemen Hutan Tropika, 18(2), 100-109. http://doi.org/10.7226/jtfm.18.2.100

Hidayati, N., Glen, M., Nurrohmah, S., Rimbawanto, A., \& Mohammed, C. (2014). Ganoderma steyaertanum as a root-rot pathogen of forest trees. Forest Pathology, 44(6), 460-471. http://doi.org/10.1111/efp.12142

Hidayati, N., \& Hendrati, R. L. (2018). Inventarisasi dan identifikasi penyebab penyakit pada Acacia auriculiformis di Yogyakarta. Jurnal Pemuliaan Tanaman Hutan, 12(2), 105-113. http://doi.org/10.20886/jpth.2018.12.2.105-113

Hidayati, N., \& Nurrohmah, S. H. (2015a). Karakterisasi morfologi Ganoderma steyaertanum yang menyerang kebun benih Acacia mangium dan Acacia auriculiformis di Wonogiri, Jawa Tengah. Jurnal Pemuliaan Tanaman Hutan, 9(2), 117-130. http://doi.org/10.20886/jpth.2015.9.2.117-130

Hidayati, N., \& Nurrohmah, S. H. (2015b). Uji somatik inkompatibilitas Ganoderma steyaertanum yang menyerang kebun benih di Wonogiri, Jawa Tengah. Jurnal Penelitian Hutan Tanaman, 12(2), 93-104. http://doi.org/10.20886/jpht.2015.12.2.93-104

Irianto, R. S. B., Barry, K., Hidayati, N., Ito, S., Fiani, A., Rimbawanto, A., \& Mohammed, C. (2006). Incidence, spatial analysis and genetic trial of root rot of Acacia mangium in Indonesia. Journal of Tropical Forest Science, 18(3), 157-165. 
Minarsih, H., Lingga, N., Darmono, T., \& Herliyana, E. N. (2011). Analisis keragaman genetik Ganoderma spp . yang berasosiasi dengan tanaman kakao dan tanaman pelindungnya menggunakan Random Amplified Polymorphic DNA ( RAPD ). Menara Perkebunan, 79(1), 6-14.

Moncalvo, J. M., Wang, H. F., \& Hseu, R. S. (1995). Gene phylogeny of the Ganoderma lucidum complex based on ribosomal DNA sequences. Comparison with traditional taxonomic characters. Mycological Research, 99(12), 1489-1499. http://doi.org/10.1016/S09537562(09)80798-3

Nurrohmah, S. H., \& Hidayati, N. (2014). Uji inkompotibilitas somatik dan pertumbuhan jamur Ganoderma dari kebun benih generasi pertama Acacia auriculiformis di Wonogiri, Jawa Tengah. Jurnal Pemuliaan Tanaman Hutan, 8(1), 14-29.

http://doi.org/10.20886/jpth.2014.8.1.14-29

Rahmawati, D., Khumaida, N., \& Siregar, U. J. (2019). Morphological and phytochemical characterization of susceptible and resistant sengon (Falcataria moluccana) tree to gall rust disease. Biodiversitas, 20(3), 907-913. http://doi.org/10.13057/biodiv/d200340

Suryantini, R., \& Wulandari, R. S. (2018). Diversity of ganoderma pathogen in pontianak, West Kalimantan: Characteristics, virulence and ability to infect Acacia mangium seedlings. Biodiversitas, 19(2), 465-471. http://doi.org/10.13057/biodiv/d190213
Wang, D.-M., Wu, S.-H., Su, C.-H., Peng, J.-T., Shih, Y.-H., \& Chen, L.-C. (2009). Ganoderma multipileum, the correct name for "G. lucidum" in tropical Asia. Botanical Studies, 50(4), 451-458.

Wang, X.-C., Xi, R.-J., Li, Y., Wang, D.-M., \& Yao, Y.-J. (2012). The species identity of the widely cultivated ganoderma, "G. lucidum" (ling-zhi), in China. PLoS ONE, 7(7), e40857. http://doi.org/10.1371/journal.pone.0040857

Widyastuti, S. M., \& Riastiwi, I. (2013). Toleransi Tanaman Peneduh Polyalthia Longifolia dan Pterocarpus Indicus Terhadap Ganoderma sp. Jurnal Hama Dan Penyakit Tumbuhan Tropika, 13(1), 19-23.

Xing, J. H., Sun, Y. F., Han, Y. L., Cui, B. K., \& Dai, Y. C. (2018). Morphological and molecular identification of two new Ganoderma species on Casuarina equisetifolia from China. MycoKeys, 34, 93-108. http://doi.org/10.3897/mycokeys.34.22593

Yang, Z. L., \& Feng, B. (2013). What is the Chinese "Lingzhi"? - a taxonomic mini-review. Mycology, 4(1), 1-4. http://doi.org/10.1080/21501203.2013.774299

Zhou, L. W., Cao, Y., Wu, S. H., Vlasák, J., Li, D. W., Li, M. J., \& Dai, Y. C. (2015). Global diversity of the Ganoderma lucidum complex (Ganodermataceae, Polyporales) inferred from morphology and multilocus phylogeny. Phytochemistry, 114, 7-15.

http://doi.org/10.1016/j.phytochem.2014.09.023 
J urnal Pemuliaan Tanaman Hutan

Vol. 14 No. 1, Juni 2020, p. 57 - 63 